To perform its tasks effectively, the research partnership must be the object of thoughtfully constructed policies and of mutual accommodation between the partners. Dupré and Lakoff display very fairly the conflicts that arise between Government and industry, between Government and universities, the clashes of loyalty involved which are frequently independent enough of the specific characteristics of national institutions but derive from the nature of the university, or of industry, or of Government itself. Whether they are concerned with the formulation of policy or with the stuff of politics, the major challenge thrown down to organization if the relations between science and Government are to function smoothly is as manifest in this book by Dupré and Lakoff as in the Carr Report: it can neither be mistaken nor ignored by the scientist.

\section{THE NERVOUS SYSTEM}

\section{Experimental Neurology}

By Prof. Paul Glees. Pp. xii +532. (Oxford: Clarendon Press; London: Oxford University Press, 1961.) 75s. net.

CHIS book is a translation of a book published in German by the author in 1957. The lapse of time has made some amplification possible. Dr. Glees is well known for his contributions to neurohistology. The book begins with a description of the methods used to investigate the finer anatomy of the nervous system with particular reference to the tracing of the degeneration resulting from experimental lesions, and goes on to review the methods used for the study of nervous activity, including the investigation of evoked potentials by electroencephalography and the study of behaviour. Nowadays, the old distinction between anatomy and physiology has disappeared in the sense that in a large field of experimental neurology the study of the one without the other would be meaningless. Hence Dr. Glees takes the reader through the anatomo-physiology of the nervous system from the peripheral receptors by way of nervous conduction and the synapses to the spinal cord and thence to the various anatomical structures at higher levels until he reaches the cerebral cortex.

Clearly a book, even of this size, cannot hope to cover all aspects of both neuroanatomy and neurophysiology. There are therefore gaps. For example, an account of the differing rates of conduction in fibres of different sizes in the peripheral nerves does not mention the attempt to correlate these with particular forms of sensibility. It is a little difficult to know how speech comes into experimental neurology, but if it is to be included it should not be limited to a description of 'centres' for motor speech and writing even with the admission that "the word 'centre' for these areas tends to give $\left[\mathrm{b}_{0}\right]$ false impression".

Nevertheless this book, which is well produced, well illustrated and very well documented with references, fills a real need, and will be of value to a wide range of readers who want to know what is happening in the important, but nowadays highly technical, field of experimental neurology.

LORD BRAIN

\section{FRÉDÉRIC JOLIOT-CURIE}

Frédéric Joliot-Curie et l'Energie Atomique

Par Pierre Biquard. (Savants du Monde Entier, Nr. 3.) Pp. 255. (Paris: Éditions Seghers, 1961.) n.p.

7 HIS is a paper-back volume, in French, in the series Savants du Monde Entier. The standard of the biographies which have appeared already is high and the promised volumes, which rango from Aristotle to
Leriche, Fermi, Cuenot and Branly, will be awaited with interest.

The author of the book is pleasantly objective and, so far as possible, allows the story to tell itself in terms of original documents. Joliot was born on March 19, 1900, entered the laboratory of Marie Curie in October 1925, married her daughter Irène a year later, was awarded the Nobel Prize in Chemistry in 1935, claimed the fission of uranium in 1938, and started up the small atomic pile $Z o \ddot{~}$ in 1948. He died in 1958 , two years after his wife.

Joliot, the son-in-law of Marie Curie, owed much to mother and daughter; but he had an original mind, great technical skill and an inventive genius. He was a man of wide attainments : he played the piano and painted effectively. $\mathrm{He}$ read widely and, surprisingly, was devoted to the works of Kipling, some of which had been translated by his wife. The rational, anti-clerical outlook of the Curies suited his socialism. He was 'a citizen of the world' and was active in the movements for the use of science in the cause of peace and the improvement of the lot of man. There is a danger that his activities as a communist may obscure, in the Western mind, his real achievements as a physicist. There can be no doubt of his absolute sincerity in his political ideas in relation to the catastrophic possibilities for mankind in the applications of nuclear physics.

The stories of the beryllium rays, which were an important step in Chadwick's discovery of the neutron; the production of artificial radioactivity; the sorting out of the real nature of the so-called trans-uranic elements are well told. Joliot's favourite instruments were C. T. R. Wilson's cloud-chamber, which he improved, and the Geiger counter. Unlike so many atomic scientists in other parts of the world, he always remembered with gratitude the sources of these simple and beautiful funda. mental instruments of atomic research.

The documentation is excellent, and the appendixes contain lists of all Joliot-Curie's publications, jointly with his wife and separately, a list of his lecture courses, a bibliography of works devoted to him and a useful glossary, in French, of terms used in nuclear physics. The illustrations are varied and informative. Among others, these include reproductions of pages of the laboratory note-books of Joliot-Curie, a picture of him with his favourite cloud-chamber apparatus, an example of his landscape painting and a photograph of the crowd at his funeral.

W. L. Sumner

\section{ASPECTS OF PHYSICAL CHEMISTRY}

\section{Annual Review of Physical Chemistry}

Vol. 13. Edited by H. Eyring, Associated Editors: C. J Christensen and H. S. Johnston. Pp. vii +528. (Palo Alto, California: Annual Reviews, Inc., 1962.) 7.00 dollars (United States); 7.50 dollars (elsewhere).

THE present volume of this highly valued review of physical chemistry contains 21 articles covering the usual proportion of old and new titles. This means that individual chapters are fairly short and when it is found that there are some 3,285 references in the bibliographies it will be appreciated that the treatment, apart from being selective, is concise. All the same, most of the authors have contrived to make their reviews interesting. A new feature, which is to be repeated, consists of a chapter of reminiscences by a veteran physical chemist. In view of the great compression of the factual articles it is questionable whether this will be welcomed by all readers.

It is obvious that not even a list of titles can be provided and only $a_{\text {few }}$ aspects of the volume can be mentioned. There are many useful tables of results. The discrepancy in the values of the bond length $\mathbf{C}-\mathbf{H}$ found by two different groups of methods is not resolved. The chapter on 